International Journal of Business Management, Entrepreneurship and Innovation, Volume 4, Issue 1, 2022, PP 1-19, ISSN 2707-8027

BMED

\title{
Operations Strategies and Competitive Advantage of African Airlines: A Case of Kenya Airways
}

\author{
Bett Kipkemoi Gilbert ${ }^{1}$, Jane Wanjira Njuguna ${ }^{2}$ \\ ${ }^{1}$ Student, Master of Business Administration (Strategic Management), Kenyatta University, \\ Kenya \\ ${ }^{2}$ Lecturer, Department of Business Administration, Kenyatta University, Kenya
}

ABSTRACT

In today's business environment, competitive advantage goes to those organizations most able to adopt effective operations strategies. It is believed that operations strategies are responsible for spurring competitive advantage in different organizations. As a result, many airlines have adopted diverse strategies to enable them obtain competitive advantage. However, it was still unclear whether these strategies actually contributed to the envisaged competitive advantage. This study was carried out to ascertain whether the operations strategies adopted had any significant influence on competitive advantage of Kenya Airways. The specific objectives of the study were to establish the influence of operational efficiency, product and service innovation, continuous process improvement and customer orientation on the competitive advantage of Kenya Airways. The study was guided by the rational choice theory, resource-based view theory, the neoinstitutional theory and the Porter's Five Forces Model. The study was anchored on the descriptive survey design and targeted senior and middle level operations managers at the Kenya Airways headquarters in Embakasi, Nairobi and the Jomo Kenyatta International Airport that serves as the operations hub to Kenya Airways. The study was a census comprising of 125 study participants. Data was collected using a questionnaire. A pilot study was carried out to guarantee the reliability of the instrument. Reliability was tested using Cronbach alpha and Cronbach alpha reliability coefficient of 0.78 was obtained and deemed satisfactory. Descriptive and inferential statistics were utilized to analyze the data. Descriptive statistics included means, frequencies, percentages and standard deviation while the inferential statistics included Pearson's correlation and multiple regression analysis. Statistical Packages for Social Sciences (SPSS) software was utilized to examine the data. The findings showed that the regression coefficient of operations efficiency was 0.309 ( $p$-value $=0.001)$, innovation of product and services was 0.321 (p-value $=0.002)$, continuous improvement was 0.223 ( $p$-value $=0.002$ ) and customer orientation was 0.137 (p-value $=0.000)$. The results revealed that $30.9 \%$ of the variance observed in the competitive advantage of Kenya airways was influenced by operational efficiency while $32.1 \%$ was influenced by innovation of product and services. Also $22.1 \%$ of the variance in competitive advantage was contributed by continuous process improvement while $13.7 \%$ was influenced by customer orientation. The study concludes that for airlines to achieve competitive advantage they must focus on reducing flight delays and cost of operations, conform to operational charter and the overall corporate strategy, strive to offer superior products and services, explore new routes, introduce new aircrafts and offer attractive products and services, maintain a culture of continuous improvement and learning by availing the products and services that fulfill and satisfy the unique needs of the customers as well as their demands. The study recommends that the management of airlines should ensure that their operations are efficient and invest more in research to identify new products and services. The management of airlines should also ensure that they adopt products and services that meet customers' needs and satisfaction. 
International Journal of Business Management, Entrepreneurship and Innovation, Volume 4, Issue 1, 2022, PP 1-19, ISSN 2707-8027

BMED

Key Words: Operations Strategies, Competitive Advantage, Kenya Airways

DOI 10.35942/ jbmed.v4i1.227

\section{Cite this Article:}

Bett, G., \& Njuguna, J. (2022). Operations Strategies and Competitive Advantage of African Airlines: A Case of Kenya Airways. International Journal of Business Management, Entrepreneurship and Innovation, 4(1), 1-19. https://doi.org/10.35942/jbmed.v4i1.227

\subsection{Introduction}

In modern business environment which tends to be dictated by heightened and stiff competition, nearly all profit and not for profit businesses are compelled to adopt strategies that place them ahead of their competitors (Ireland, Hitt \& Sirmon, 2018). Thus, most organizations have become focused on identifying and implementing operational strategies that would enable them enjoy good reputation (Adnant, 2017; Hill, Jones \& Schilling, 2018). Lumpkin and Dess (2019) aver that every business ought to have its own well-articulated strategies that promote its overall performance. To this end, operations strategies have become part and parcel of the management of airlines because they provide a roadmap on how resources are applied to obtain competitive advantage (Slack, 2015). Globally, airlines have developed unique set of operations strategies to outperform competitors (Winston \& Crandall, 2014). In the European air transport, for example, operations strategies have increasingly become considerably significant given that a host of airlines generally tend to seek to improve and maintain their overall competitiveness. In Britain, for instance, the movement towards business liberalization opened the previously rigidly regulated aviation market, an act that provided new rights for new airlines operators. Consequently, low-cost carriers (LCCs) took advantage of the new regulatory adjustment in the European air transport to open routes and gain considerable market share thus revolutionizing the way people travel (Shehu \& Mahmood, 2018). In the Asian countries, it was the aviation deregulatory pressures and the desire of the growing middle class for air travel that effectively reshaped for good how the aviation industry was conducted (Gross \& Luck, 2019). These dynamics have accelerated the adoption of new strategies to comply with the rapid demographical changes and advancements in economic conditions. Nevertheless, most Asian airlines are still confronted by both financial and management challenges which have regrettably interrupted some passenger services (Wang, 2018). In Turkey, for instance, technological changes which seem to be guided by customer satisfaction appear to be the most invigorating strategies influencing competitive advantage (Shehu \& Mahmood, 2018).

In Africa, the increasing reliance on air transportation occasioned by the rising demand for affordable travel options gradually resulted in the introduction and expansion of affordable lowcost airline models. Prisco (2016) concurs that the low cost model is important in the African context because of its ability to promote the growth of the aviation industry as it enables more people to pay for the cost of air travel. Despite the availability of the low cost crafts, it is still difficult to manage aviation related businesses as many airlines have continued to make losses (Matsilele, 2016). In Nigeria, most airlines have been liberalized through restructuring strategies which have allowed private airlines to use the government aviation infrastructure. This has intensified competition and airline providers sadly have no available option, but to look for novel ways to reposition their businesses in ways that would guarantee them growth impetus and competitive advantage. Kenya Airways came into existence in the business world 1977, upon the 
International Journal of Business Management, Entrepreneurship and Innovation, Volume 4, Issue 1, 2022, PP 1-19, ISSN 2707-8027

\section{BMED}

publicized decreed insolvency of the East African Airways. It has blossomed over the years and is currently the undisputable flag carrier airline of Kenya whose head office is strategically located in Embakasi, Nairobi and the air transport hub based at the JKIA. Originally the airline was exclusively possessed by the government until 1995 when business dynamics compelled the government to invite public partnerships through privatization. Currently, Kenya Airways operates as a joint venture with both public-private partnership where the government controls $48.9 \%$ of the available shareholding. In East Africa, Kenya airways dominate the air transport market. Due to stiff competition, it is only Kenya airways, Precision Air and Rwanda Air Express that have managed to remain operational by adopting collaborative strategies and alliances (Ouma, 2018). However, Kenya airways is the dominant airline and Nairobi has been considered as a gateway of Eastern and Southern Africa for air travel. Like other airlines in the world, Kenya airways has adopted a series of operations strategies to enable it to survive in the increasingly difficult business environment. These includes building alliances including joint ventures, expanding route networks and securing direct access to new markets (Wandiga \& Kilika, 2017). Nevertheless, the airline has regrettably been unable to harness the advantage presented by these operations strategies to scoop the extraordinary competitive advantage particularly with regard to the present safety measures and health protocols brought by covid 19 pandemic. Moreover, recent studies have pointed out that Kenya airways has not benefitted from all the measures instituted to revamp the industry (Mokamba, Gakure \& Keraro, 2018).

According to Ouma (2018) Kenya airlines is currently experiencing challenges occasioned by hiring of expensive aircrafts and staff lay off. In spite of adopting different operations strategies the airline has not reported improved profitability as it has continued to make losses since 2012 (Alushula, 2021). For instance, it was in 2012 that the company last made some profit closing with net earnings of Ksh1.66 billion ( $\$ 15$ million). Since then huge accumulated losses have bedeviled the company worsening its equity position from Ksh17.89 billion ( $\$ 163$ million) in 2019 to Ksh 64.2 billion ( $\$ 585$ million) making it technically and financially incapacitated and insolvent (Alushula, 2021). Sky rocketing indebtedness combined with unprecedented flight delays has contributed to the huge loss of revenue. This turn of events coupled with the fall in tourism industry following terror attacks, restrictions associated with covid-19 pandemic have dealt the biggest and irrecoverable blows to Kenya Airways thus calling for institution of novel innovative operations strategies. However, it was necessary to carry out an elaborate empirical investigation to ascertain the perceived influence of operations strategies on competitive advantage of Kenya airways.

\subsection{Statement of the Problem}

Over the years, Kenya airways has assumed diverse operations strategies in order to improve its overall competitive advantage. However, it has continued to report dwindling fortunes in its financial performance. For instance, the Kenya airways posted huge losses with passenger revenue dropping by 67.5 per cent and the total income dipped by 58.9 per cent in 2020 . The latest loss means that Kenya airways has gone for eight years on a loss making spree, expanding its accumulated losses to a whooping Ksh.128.76 billion ( $\$ 1.2$ billion). This created uncertainty in the organization thereby threatening its ability to remain competitive. Considering the significant role played by the Kenya airways, different operations strategies have been adopted to enhance competitive advantage. Although previous scholarly works and empirical studies have extensively delved into the obvious factors determining competitive advantage in different organizations, most of these studies have not established the probable association between operations strategies and organizational competitive advantage especially in the aviation sector (Omondi, 2019; Gitau, 
International Journal of Business Management, Entrepreneurship and Innovation, Volume 4, Issue 1, 2022, PP 1-19, ISSN 2707-8027

\section{BMET}

2019; Tanui, 2015; Oladepo, 2018; Lekhanya, 2018; Reid, 2017). In addition, most of the studies have not been carried in airlines while those that have targeted the airlines have not addressed all the operations strategies that can be employed to realize competitive advantage. This presented both the empirical and thematic gap in relation to operations strategies and competitive advantage in organizations. Hence, this study sought to determine the influence of operations strategies on competitive advantage of Kenya airways.

\subsection{Objectives of the Study}

The study's overall objective was to assess the influence of operations strategies on competitive advantage of Kenya Airways.

Specific objectives were:

i. To establish the influence of operational efficiency on competitive advantage of Kenya airways.

ii. To investigate the effect of innovation of product and service on competitive advantage of Kenya airways.

iii. To find out if continuous improvement affects competitive advantage of Kenya airways.

iv. To determine the influence of customer orientation on competitive advantage of Kenya Airways.

\subsection{Literature Review}

\subsection{Theoretical Review}

This section discusses the theories that guided the study. In this study three major theories in strategic management were considered as citadel in the theoretical framework.

\subsubsection{The Neo-Institutional Theory}

The neo-institutional theory is associated with the works of the sociologist John Meyer in 1977. This is one of the major theoretical perspectives frequently adapted to attempt to understand and explain organizational behavior including how organizations work to realize competitive advantage. It agglutinates management, historical, sociological, psychological, anthropological, economic and rational factors that determine the processes of institutional reformation and growth. According to Fredriksson and Pallas (2015) the neo-institutional theory clearly attempts to present a frame of reference for conceptualizing the institutional changes by envisaging signposts of innovation, economics, social pressure, institutional diversity and variation. In this regard, the theory asserts that competitive advantage in an institution emanates from the entrenchment of the enabling factors that influence organizations to search for economic and social fits that lead to organizational survival. The link between neo-institutional theory and competitive advantage can be seen in the role of the theory in creating, maintaining and changing institutions based on the crucial role of operations strategies. The theory has been used to support previous studies on competitive advantage which have focused on how institutional pressures provide impetus and legitimacy to search for effective and better operational strategies (Daud \& Yusoff, 2017). For example, the theory has been used to support the idea that if operational efficiency is adopted as an operations strategy, it would most likely and inevitably influence the overall firm's competitiveness. This is because the theory offers a powerful approach for the study of competitive advantage as it provides a theoretical foundation to examine a wide range of critical operational 
International Journal of Business Management, Entrepreneurship and Innovation, Volume 4, Issue 1, 2022, PP 1-19, ISSN 2707-8027

\section{BMET}

issues that contribute to organizational competitive advantage (Greenwood, 2018). This theory is pertinent to the investigation as it portrays the significance of operational efficiency in guaranteeing competitive advantage in an organization. Therefore, this theory was used to guide this study to ascertain whether operational efficiency influenced competitive advantage of Kenya airways.

\subsubsection{Resource-Based View Theory}

The resource base view theory (RBV) was started by Barney Jay in 1991. The theory views organizations as being simply a collection of capabilities where income comes from ownership and control over the generally scarce or limited resources. In essence, the theory posits that organizations can only achieve and sustain competitive advantage by acquiring, managing and deploying key scarce resources. The theory also considered a firm's internal characteristics to explain its strategy and performance. In this context, Kenya airways can be considered as an economic institution in that it uses the scarce resources to manufacture goods and services of value. According to Werner (2019) the strategic foundation of a firm is formed based on the basis of availability of these generally limited or scarce resources. This was evident in a study by Newbert (2016) which seemed to portend that in comparison to competitors, many organizations may generally attempt to gain competitive advantage by deploying its erstwhile limited resources to generate more and more economic resources. Because the concept of value addition is an aspect of economic generation which coheres with product and service innovation, the theory was considered relevant in this study. In this regard, the theory was used to guide this study because it explained how product and service innovation influenced competitive advantage of Kenya airways.

\subsubsection{Rational choice theory}

Rational choice theory was pioneered by Adam Smith in 1776. The theory is a framework for understanding both the social and economic behavior of organizations. Its basic premise is that in reality aggregate social behavior especially in group situations results from the behavior of individual actors, each of whom actively makes her or his personal decisions. It also states unequivocally the that individuals in sound minds use rational as well as mathematical calculations to make rational self-serving choices, consequently achieving outcomes that are aligned holistically with their unique objectives and best self-interests. As a result, organizations often make decisions that are expected to result into outcomes that lead to not just competitive advantage but economically beneficial outcomes for the organization. This theory has been used to guide many studies in strategic management. For example, Krebs (2018) revealed that organizations are motivated to invest in employees' skills development in order to reap benefits in terms of competitive advantage. It is on this basis that this study was guided by the rational choice theory to help understand why Kenya airways engage in continuous process improvement. It was hypothesized that by engaging in continuous process improvement, Kenya airways would be making a rational choice to try to maximize competitive advantage. The economic benefits of continuous process improvement were rationalized to result into competitive advantage. Thus, this theory is pertinent to the research as it depicted the importance of continuous process improvement in ensuring competitive advantage of Kenya airways.

\subsection{Empirical Review}

\subsubsection{Operational Efficiency and Competitive Advantage}


International Journal of Business Management, Entrepreneurship and Innovation, Volume 4, Issue 1, 2022, PP 1-19, ISSN 2707-8027

BMED

A host of previous research studies have attempted to examine how operational efficiency can really be manipulated and adopted to determine competitive advantage of organizations across the world. Levin (2019) studied the impact of operations strategies on competitive advantage in chain stores in Minnesota, USA. In order to acquire the necessary information, the study adopted the self-generated questionnaires to gather data and objectively anchored the study on the descriptive survey design. Primary data was collected from 101 purposively selected store chain link managers. Being guided by the structural equation modelling approach, the empirical results evidently showed that operational efficiency resulted into short turn-rounds, economies of scale and low operation costs. In spite of generating significant results, the results could not be applicable in the present study due to the fact that the study was conducted in chain stores due to the fact that the study was conducted in chain stores. Jussi (2016) empirically undertook a primary study in Finland on the perceived potential role of operational efficiency in enhancing competitive advantage in Finnish insurance companies. The study considered the ex post facto as the appropriate design. The primary qualitative data was gathered through interviews with operational managers and senior level employees of selected insurance companies. The findings revealed that the insurance businesses' operational efficiency allowed them to stay competitive in the face of strong competition from competitor organizations. After careful scrutiny, however, it could be deduced that the findings were not completely applicable with the present predicament at the Kenya airways. Also the study differs methodologically as it utilized the ex post facto design. In another rather related study, Bagherzadeh and Jöehrs (2015) embarked on investigating the extent to which operational efficiency as an internal framework was responsible for institutional competitiveness. In order to accomplish the study's goals, the researcher inherently adopted a qualitative design with the primary data being gathered through interviews with the relevant interviewees for two years. After interrogating the findings, it was evident that loss of institutional competitiveness was the result of inefficiency of organizational strategies. The study concluded that operational efficiency was very critical in business processes. To a very great extent, this research shed light on the role of operational efficiency in ensuring competitive advantage but its focus was not in airlines as current in the present study.

Being anchored on a survey design consisting of 78 management employees derived from the selected sugar processing firms in Kenya, Ofunya (2019) interrogated the determinants of the perceived competitive advantage in the sugar sector. Furthermore, competitive advantage in this study was the criterion variable with operational efficiency considered as an independent variable of interest. The study revealed that operational efficiency enabled the sugar factories to increase productivity and quality of sugar thus managing to keep up with the competition in the market. Although the study shared a host of similarities with the present study, it was, however, not contextually sharing similar context thus rendering its findings inapplicable to Kenya airways. In addition, its failure to clearly describe the specific target population and sampling design outrightly renders the findings un-generalizable in the present research conditions. In an attempt to identify study gaps, a study by Karimi (2019) was reviewed. In this study, Karimi (2019) undertook to explore empirically, objectively and elaborately the perceived influence of efficiency of operations in relation to competitive advantage of Kenya's large pharmaceutical firms. The production departments of the selected firms served as the unit of analysis in this study, with a total of 203 employees sampled. The study considered the descriptive survey design relevant as its methodological procedure. The results revealed that owing to economies of scale it was possible to increase production volume which gave the firms competitive advantage over small farms. It 
International Journal of Business Management, Entrepreneurship and Innovation, Volume 4, Issue 1, 2022, PP 1-19, ISSN 2707-8027

\section{BMMED}

was also evident that large that firms that focused on efficiency in production were more proactive than their competitors. As it was evident, the results may not actually and realistically be generalized to Kenya airways given that the reviewed study was carried out in pharmaceutical firms. Focusing on carefully selected DTSs in Bungoma County, Kulundu (2017) set out to examine the possible influence of operational efficiency on the competitive advantage. In his study, the anticipated primary data was carefully gleaned from a sample size of 56 respondents by applying semi-structured questionnaires and the gathered data was eventually analyzed inferentially by applying the regression and correlation analysis. It was evident from this study that operational efficiency was not only statistically significant but also related linearity with competitive advantage in the considered DTSs. In spite of revealing a positive relationship, the unit of analysis differs from the present study whose focus was on the Kenya airways.

\subsubsection{Product and Service Innovation and Competitive Advantage}

The impact of innovation has been scholastically examined in a plethora of past empirical investigations. Some of these research were examined in this regard in order to discover study gaps and to guide the proposed study. Nur, Topsekele and Dogan (2018) undertook to ascertain whether the various forms of innovation could determine Antalyan airline's competitive advantage. The study design hinged on the well framed survey design with a study sample of 350 airline employees. Using the regression analysis as the key data analysis procedure, the close perusal of the results led to conclusion that both product and service innovations were associated with airline's competitive advantage. Although the reviewed study was significant and seemed to connect product and service innovation to the expected competitive advantage, the fact that it was based in a different locally rendered the findings inapplicable in the Kenyan context thus the findings may not be applicable to Kenya airways mainly due to the methodological difference. Urbancová (2019) was concerned about the possibility of achieving institutional competitive advantage through product innovation in financial institutions in the Czech Republic. To procedurally undertake the study, a case study approach was chosen with the data being gathered from a sample of 450 respondents working as managers of various branches of the selected commercial banks. After carefully studying the gathered data, it was evident that introduction of new financial products provided competitive advantage for the commercial banks. Although this study has ascertained the existence of a positive relationship between two variables, it differed from the current study methodologically given that it was focusing on financial institutions while the proposed study focused on the case study of Kenya airways.

In Pakistan, Commer (2019) attempted to determine the potential connection or link among marketing, product and process innovation and the generally expected competitive advantage in selected companies whose main activity was manufacturing. In this reviewed study, a survey design was adopted given that the intention was to basically describe the prevailing state of affairs using secondary data. The results revealed that product innovation gave the companies competitive edge over other companies that relied on traditional product designs. This study differed from the current one which sought to combine both the service and product innovations but in the context of Kenya airways. Owino (2019) studied the innovative strategies embraced by NonGovernmental organizations (NGOs) in Kenya to realize competitive advantage. Because the selected NGOs were situated in diverse locations, the study opted to employ the survey design. The study was theoretically anchored on the resource based theory with the simple random sampling being embraced participants' identification. Moreover, the researcher settled on the semistructured questionnaire as the data gathering instrument with the regression analysis as the 
International Journal of Business Management, Entrepreneurship and Innovation, Volume 4, Issue 1, 2022, PP 1-19, ISSN 2707-8027

\section{BMMED}

approach considered in data analysis. Based on the evidence deduced from the findings, it was concluded that innovative strategies adopted by the NGOs did not result into a significant competitive advantage. This study shed insurmountable light on the perceived role of novel strategies but it did not specific the innovative strategies which could be applicable in the present study.

Moreover, Naikuni (2015) delved into the potential nexus between appropriate service innovation and the perceived competitive advantage in the hospitality industry in Kenya. Methodologically, the descriptive design was adopted with the stratified random sampling considered as the scientific basis for selecting 149 representative study participants from five diverse hotels. Given that quantitative data was gathered via a standard questionnaire, inferential statistics evidently became necessary to be adopted to analyze data to ascertain clearly the kind of correlation among the selected study variables. Holding all other factors constant, the results suggested that service innovation directly influenced competitive advantage in the identified hotels in Nairobi County. However, a strong association was not discerned as anticipated thus rendering the results inapplicable in the present study. This provokes further study to examine and analyze the same phenomenon at the Kenya airways. Moreover, based on a mixed method design, Muiruri (2018) explored the impact of financial innovation on Kenyan airlines' competitive advantage. In this study, the quantitative data was simultaneously gleaned through the utilization of questionnaire after which inferential statistics were considered in data corroboration and analysis. As initially hypothesized, a critical assessment of the findings averred that indeed financial innovations greatly impacted on the level of competitiveness of airlines in Kenya. However, in this study, financial innovation was not considered as an operational strategy making the results quite applicable in the present study. In addition, the findings cannot be applied in the current study because the focus was not on one airline but in many airlines. Also, the current study relied on a case study and not a mixed method approach.

\subsubsection{Continuous Process Improvement and Competitive Advantage}

According to Lambkin (2017) improvement of processes is primarily triggered by major organizational changes notably mergers and acquisitions which tend to transform future trends in the concerned organizations. Recent studies evidently reveal the significant link between improvement of processes and institutional competitiveness. One of the relevant studies was conducted by Pradeep and Shah (2015) to ascertain the perceived impact of continuous process improvement in some hotels in India. The investigators were concerned about specific aspects of process improvement with emphasis on brand name and organizational competitiveness. Consequently, the study focused on examining empirically how this aspect of process improvement would contribute to the variance in organizational competitiveness using a dataset of 19,775 detailed annual financial performances from 50 hotels over an 8-year period. They compared a set of 25 rebranded hotels to a second set of 25 hotels that were carefully matched to the rebranded hotels, except that they did not rebrand. They then analyzed the performance differences between the two sets. It was evident that competitive advantage appeared to be a function of branding as a form of improvement of processes. Although the study appreciated the role of process improvement, it was not conducted in airlines.

In Pakistan, Sundus and Naintara (2018) elaborately examined the perceived effect of improvement of processes on customer loyalty solely focusing on the Pakistani airlines. The researchers selected improvement of processes as the predictor variable which the study 
International Journal of Business Management, Entrepreneurship and Innovation, Volume 4, Issue 1, 2022, PP 1-19, ISSN 2707-8027

\section{BMMED}

manipulated to determine its consequential effect on customer loyalty which was scientifically identified as the study's dependentvariable. For the benefit of the study, the outcome contended that customer loyalty could not singly reverse the owing to the adjustment to the envisaged processes. Although considered appropriate guide to the study, it didn't look into it directly the perceived impact of improvement of processes on competitive advantage in Kenya not the least its failure to conceptualize customer loyalty with regard to competitive advantage. Huang (2019) investigated the possible impactful adoption of technological innovation to realize organizational competitive advantage in commercial airlines in Singapore. Paired-samples analyses were conducted on the selected airlines based on pre-and post-performance audit. The results clearly suggested that in the studied airline, customer enquiry significantly improved for airlines that had strategically installed new marketing technology compared to those that had not. While this study analyzed the impact of technological adoption in airlines, it was noted that the results may not wholly provide reliable and adequate support for realization of competitive advantage through improvement of relevant processes in the context of Kenya airways.

Oladepo (2018) investigated the modes of continuous process improvement entrenched in an attempt to achieve desired competitive advantage in commercial banks in Enugu region, Nigeria. Relevant first hand findings were critically reviewed, thematically scrutinized as they related to continuous process improvement and perceived competitive advantage. In this particular study, the researcher adopted a mixed method approach with a bias on was adopted combining both qualitative and quantitative data collection dimensions. Applying purposive sapling design, thirty bank and customer relations managers in five purposively selected local banks constituted the study's sample size. The generated data was scrutinized and eventually analyzed as was systematically guided by the predetermined study objectives using SPSS software. A glimpse into the study findings discerned that continuous process improvement apparently had positive influence on the organizational competitiveness as perceived by the customers. However, this study was not based on airlines and the findings failed the applicability test in the context of competitive advantage of Kenya airways. Karimi (2019) adeptly pursued the purported influence of service customization on competitive advantage of mobile providers in selected outlets in Nakuru town. The study focused on digitization and automation of services in selected branches of mobile services providers in Nakuru County. The study adopted the survey approach and targeted four mobile service providers in Kenya. A self-generated questionnaire was wired to the respondents to obtain data which was carefully sorted and analyzed through inferential approaches with a bias on correlation analysis. The study noticeably found that both digitization and automation of services improved the level of customer satisfaction and organizational competitiveness. It was evident that this study considered the importance of continuous process improvement. However, the study did not focus on continuous process improvement as relate to competitive advantage of Kenya airways.

\subsubsection{Customer orientation and Competitive Advantage}

In many organizations, appropriate strategies have been adopted to influence customer orientation. In order to attract customers, organizations ought to perform better than the competitors particularly with regard to the satisfaction of customers' expressed needs. This is because customers will inevitably attribute or attach more self-serving utility to organizational products and services thus promoting perceived competitive advantage. In Australia, Reid (2017) carried out a study to determine how customer focused services was adopted in the transport sector to attract and retain customers. In the study customer focused services were the independent variable 
International Journal of Business Management, Entrepreneurship and Innovation, Volume 4, Issue 1, 2022, PP 1-19, ISSN 2707-8027

\section{IBMED}

which was expected to be manipulated to bring changes on the organizational competitive advantage as a criterion variable. The study zeroed in on the cross sectional survey design but opting to identify the respondents through probability sampling techniques from 132 transport operators with an estimated population of 5,000 public service transport operators in Sidney. The study posited that customer orientation was a significant determinant of in the train transport and significantly contributed to customer retention. It is evident that competitive advantage in the form of customer retention could be realized if organizations become responsive to customer's needs. However, the results may after all be inapplicable in the present study as the study overlooked airlines' competitive advantage. In Nigeria, Akpoghiran (2016) systematically carried out a vigorous study on customer orientation as a strategy adopted to economically promote service as well as product awareness for commercial local airlines. The study ostensibly focused on a case study with the qualitative primary data being gathered with the help of guided interviews. Owing to the nature of the study, it was only those personnel tasked with executing operations strategies within the airline who reasonably formed part of the sample size. The key analytic procedure adopted was the thematic content analysis through which data collected from interviews was qualitatively analyzed. The results seemed to suggest that meeting customer needs was significant in enhancing competitive advantage in the airline. In all respect the results seemed to play a significant role in guiding the current study but fails in its applicability in the present study where the focus was on Kenya airways.

In South Africa, Lekhanya (2018) set to scientifically ascertain the information discrepancy that was evident concerning customer orientation and competitive advantage of listed firms in Johannesburg Securities Exchange markets. Theoretically, the study was grounded on the Hayes and Wheel wright Four Stage Model while being restricted on the descriptive design. In order to gather elaborate data the study preferred to utilize both the tape recorded interview and questionnaire. After a careful scrutiny of the results obtained, it was evident that customer responsive approaches significantly enhanced the concerned firms' competitive advantage. In retrospect, the study failed to scrutinize the perceived and expressed role of customer orientation in relation to or regard to competitive advantage of Kenya airways. Locally, there are limited studies relating customer orientation to competitive advantage in organizations. However, using a survey of marketing firms in Kenya, Kibet (2019) looked at how the collection and utilization of market intelligence information was contributed to organizational competitiveness. The results revealed that appropriate use of market intelligence information tended to result into improved competitive advantage of marketing firms. However, the study did not exhaustively tackle the perceived link between customer orientation and competitive advantage of Kenya airways.

\subsection{Research Methods}

The study used the descriptive design. In this study all operational managers of Kenya airways constituted the study population. Hence, the study target population included the management employees at the senior and middle levels or ranks. These were chief financial officer (1), chief human resource officer (1) flight operations director (1), technical director (1), sales director (1), heads of departments (11), operations officers and supervisors (50), engineers (19), managers and leads (20), planners (6), pilots (9) and procurement officers (5) at the Kenya airways. A census was taken for all the 125 senior and middle level operations management employees at Kenya airways. The study depended on primary sources of data. In this regard, the study applied a semistructured questionnaire to collect primary data. In the current study, descriptive statistics in the form of percentage, frequency, mean and standard deviation were applied in analyzing data. The 
International Journal of Business Management, Entrepreneurship and Innovation, Volume 4, Issue 1, 2022, PP 1-19, ISSN 2707-8027

E.

analysis was carried out with the assistance of SPSS version 25. In this study, the relationship and the influence of the independent variables on the dependent variable were determined through both the Pearson's correlation and regression analyses.

\subsection{Data Analysis Results}

The linear association of interest in the study between the independent variables in conformity with the dependent variable was investigated using Pearson's correlation analysis as shown in Table.

Table 1: Pearson Correlation Analysis Results

\begin{tabular}{|c|c|c|c|c|c|c|}
\hline & & $\begin{array}{l}\text { Competitive } \\
\text { advantage }\end{array}$ & $\begin{array}{l}\text { Operations } \\
\text { efficiency }\end{array}$ & $\begin{array}{l}\text { Innovation of } \\
\text { product/services }\end{array}$ & $\begin{array}{l}\text { Continuous } \\
\text { improvement }\end{array}$ & $\begin{array}{l}\text { Customer } \\
\text { orientation }\end{array}$ \\
\hline $\begin{array}{l}\text { Competitive } \\
\text { advantage }\end{array}$ & $\begin{array}{l}\text { Pearson } \\
\text { Correlation } \\
\text { Sig. (2-tailed) }\end{array}$ & 1 & & & & \\
\hline $\begin{array}{l}\text { Operations } \\
\text { efficiency }\end{array}$ & $\begin{array}{l}\text { Pearson } \\
\text { Correlation } \\
\text { Sig. (2-tailed) }\end{array}$ & $\begin{array}{c}0.309 * * \\
0.001\end{array}$ & 1 & & & \\
\hline $\begin{array}{l}\text { Innovation of } \\
\text { product and } \\
\text { services }\end{array}$ & $\begin{array}{l}\text { Pearson } \\
\text { Correlation } \\
\text { Sig. (2-tailed) }\end{array}$ & $\begin{array}{c}0.321 * * \\
0.007\end{array}$ & $\begin{array}{l}.255^{* *} \\
.001\end{array}$ & 1 & & \\
\hline $\begin{array}{l}\text { Continuous } \\
\text { improvement }\end{array}$ & $\begin{array}{l}\text { Pearson } \\
\text { Correlation } \\
\text { Sig. (2-tailed) }\end{array}$ & $0.223 * *$ & $.170^{*}$ & $\begin{array}{c}.275^{* *} \\
000\end{array}$ & 1 & \\
\hline $\begin{array}{l}\text { Customer } \\
\text { orientation }\end{array}$ & $\begin{array}{l}\text { Pearson } \\
\text { Correlation } \\
\text { Sig. (2-tailed) }\end{array}$ & $\begin{array}{c}0.137 * * \\
.000\end{array}$ & .301 & .298 & $\begin{array}{l}.378^{* *} \\
.000\end{array}$ & 1 \\
\hline
\end{tabular}

Table 1 shows that the correlation coefficients for operations efficiency, innovation of product and services, continuous improvement and customer orientation toward competitive advantage of Kenya airways results were shown to be all positive, with p-values of less than 0.05 . The results pointed to the extant of a positive relationship $(r=0.309, \mathrm{p}=0.001)$ amongst operations efficiency and competitive advantage. This corresponds with Khalili, Nazemi and Alborzi (2019) who asserted that efficiency of operations of airlines helped to realize competitive advantage. The innovation of product and services was considered as having a significant relationship with competitive advantage. Hence, the study clearly averred the extant of a positive relationship $(\mathrm{r}=0.321 ; \mathrm{p}=0.007)$ amongst innovation of product and services and competitive advantage. This implies that Kenya Airways has introduced innovations in its services and products with a view to obtaining competitive advantage. This has been supported by Markus (2019) who averred that economic and technological advancements are part of the success story in the aviation sector. The findings also revealed a significantly positive relationship $(r=0.223 ; \mathrm{p}=0.002)$ between continuous improvement and competitive advantage of Kenya airways. This implies that through continuous process improvement Kenya airways can prevent wastage and improve quality of the products and services offered to customers. This concurs with Barrack (2020) who affirmed that in many organizations that have embraced continuous improvement in their operations performance tends to improve drastically.

Finally, the results depict the presence of a positive relationship $(r=0.137 ; p=0.00)$ between customer orientation and competitive advantage of the Kenya airways. This implied that the competitive advantage of Kenya airways minimally dependent on customer orientation. These 
International Journal of Business Management, Entrepreneurship and Innovation, Volume 4, Issue 1, 2022, PP 1-19, ISSN 2707-8027

B.

results are supported by Zafar (2019) who noted that when customers are handled skillfully by incessantly satisfying their needs an airline was bound to achieve better results. The general regression model equation was applied to determine the influence of operations efficiency, innovation of product and services, continuous improvement and customer orientation on competitive advantage of Kenya airways, where $\mathbf{X}_{\mathbf{1}}=$ Operational efficiency, $\mathbf{X}_{\mathbf{2}}$ $=$ Product and service innovation, $\mathbf{X}_{\mathbf{3}}=$ Continuous process improvement and $\mathbf{X}_{\mathbf{4}}=$ Customer orientation as depicted in the equation 1.

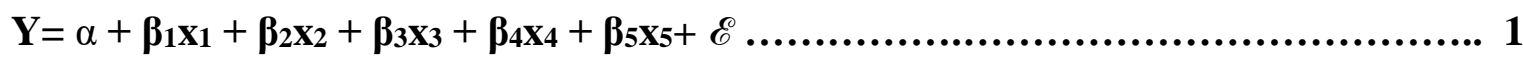

Table 2 presents the model summary of the multiple linear regression analysis.

Table 2 Model Summary of Multiple Linear Regression Analysis

\begin{tabular}{lccccc} 
Model & R & R Square & Adjusted R Square & Standard Error & Sig. \\
1 & $0.8087^{\mathrm{a}}$ & 0.654 & 0.0319 & 0.2507 & 0.0101 \\
\hline
\end{tabular}

a. Predictors:(Constant),Operations efficiency, Innovation of product and services, Continuous improvement, Customer orientation

According to the data in Table 2, the multiple regression (R) obtained was 0.8087 and the Rsquared was 0.654 . These results show that operations efficiency, innovation of product and services, continuous improvement and customer orientation collectively was responsible for $65.4 \%$ of the total variance in the competitive advantage of Kenya airways. This means that there were other factors that influenced competitive advantage of the Kenya airways but these were not taken into account by the regression model 4 . The statistical significance of the model was determined using the analysis of variance and the analytical results indicated by Table 3 .

Table 3: Analysis of Variance

\begin{tabular}{llccccc}
\hline Model & & Sum of Squares & Df & Mean Square & F & Sig. \\
\hline \multirow{4}{*}{1} & Regression & 2.975 & 4 & 0.719 & 2.643 & $0.000^{\mathrm{b}}$ \\
& Residual & 16.349 & 99 & 0.272 & & \\
& Total & $\mathbf{1 8 . 0 4 4}$ & $\mathbf{1 0 3}$ & $\mathbf{0 . 9 9 1}$ & &
\end{tabular}

a.Predictors: (Constant), Operations efficiency, Innovation of product and services, Continuous improvement, Customer orientation

\section{b.Dependent Variable: Competitive advantage}

\section{Source: Survey Data (2021)}

The ANOVA results exhibited in Table 3 show that the four study variables namely operational efficiency, innovation of product and services, continuous improvement and customer orientation were statistically significant determinants of competitive advantage of Kenya airways. In the study, the findings revealed that F-ratio $\left(\mathrm{F}_{(4,99)}=2.643\right)$ was statistically significant at $\mathrm{p}=0.000$. Moreover, the influence of operations efficiency, innovation of product and services, continuous improvement and customer orientation on competitive advantage was determined using the regression coefficients exhibited in Table 4.

Table 4: Regression Coefficients 
International Journal of Business Management, Entrepreneurship and Innovation, Volume 4, Issue 1, 2022, PP 1-19, ISSN 2707-8027

\begin{tabular}{|c|c|c|c|c|c|c|}
\hline \multirow{2}{*}{\multicolumn{2}{|c|}{ Model }} & Unstanda & & Standardized & $\mathrm{T}$ & Sig. \\
\hline & & $\mathrm{B}$ & Std. Error & Beta & & \\
\hline & (Constant) & 3.175 & 0.763 & & 3.237 & 0.000 \\
\hline & Operations efficiency & 0.309 & 0.145 & 0.041 & 0.332 & 0.001 \\
\hline 1 & $\begin{array}{l}\text { Innovation of product and } \\
\text { services }\end{array}$ & 0.321 & 0.111 & 0.309 & 2.128 & 0.002 \\
\hline & Continuous improvement & 0.223 & 0.128 & 0.097 & 0.859 & 0.002 \\
\hline & Customer orientation & 0.137 & 0.102 & 0.179 & 1.359 & 0.000 \\
\hline
\end{tabular}

\section{Source: Survey Data (2021)}

Table 4 indicates that operational efficiency, innovation of product and services, continuous improvement and customer orientation all had a positive influence on the competitive advantage of Kenya airways. Analyzing the derived multiple regression model, It is obvious that holding all the other factors constant, the beta value of 0.309 for operational efficiency implied that a unit change in operational efficiency led to a 0.309 change in competitive advantage. This implied that $30.9 \%$ of the variance observed in the competitive advantage of Kenya airways was stated by minimizing delays, adhering to the standards and reducing cost of operations. Based on the results the hypothesis which denied the presence of a statistically significant influence of operations efficiency on the competitive advantage of Kenya airways was rejected, thus accepting that operations efficiency significantly influenced the competitive advantage of Kenya airways. Jussi (2016) concurred that organizations resorted to enhancing the efficiency of their operations in order to remain competitive and overcome all forms of competition.

It was also evident that the beta value of 0.321 for innovation of product and services implied that a unit change in innovation of product and services led to a 0.321 change in competitive advantage. This means that introducing new routes, new crafts and proactive operations accounted for $32.1 \%$ of the variance observed in competitive advantage of Kenya airways. From the study findings, the hypothesis which stated that product and service innovation had no significant influence on competitive advantage of Kenya Airways was rejected. Thus, product and service innovation was found to have a positive and significant influence on competitive advantage of Kenya Airways. This is supported by Commer (2019) who noted that product and process innovation gave organizations a competitive edge over other companies that relied on traditional product designs.

The results also disclosed that the $\beta$ value of 0.223 backed up by a probability value of 0.002 signified that a unit change in continuous process improvement led to a 0.223 change in competitive advantage of Kenya airways. This means that continuous improvements, continuous learning and quality audit accounted for $22.3 \%$ change in the competitive advantage of Kenya airways. From the study findings, the hypothesis which stated that continuous process improvement had no significant influence on the competitive advantage of Kenya Airways was rejected and the study observed that continuous process improvement significantly influenced the competitive advantage of Kenya Airways. This corresponds with Pradeep and Shah (2015) who ascertained that competitive advantage was a function of branding as a form of improvement of processes. Lastly, the $\beta$ value of 0.137 backed up by a probability value of 0.000 signified that a unit change in customer orientation led to 0.137 change in the competitive advantage of the Kenya airways. In this instance, the least percentage of $13.7 \%$ of the variance in the competitive 
International Journal of Business Management, Entrepreneurship and Innovation, Volume 4, Issue 1, 2022, PP 1-19, ISSN 2707-8027

\section{BMET}

advantage was clarified by customer satisfaction, meeting customer needs and defects elimination. Analysis showed that the hypothesis which stated that customer orientation had no significant influence on competitive advantage of Kenya Airways rejected. This is backed by Akpoghiran (2016), who observed that meeting customer needs was important in increasing the airline's competitive advantage. Therefore as consequence of the regression analysis, a model equation with standardized beta coefficients was developed as shown in equation 2:

$$
\mathrm{Y}=3.175+0.309 \mathrm{X}_{1}+0.321 \mathrm{X}_{2}+0.223 \mathrm{X}_{3}+0.137 \mathrm{X}_{4}
$$

Using open-ended questions, the respondents were requested to clarify their feelings about the influence of operations efficiency, innovation of product and services, continuous improvement and customer orientation on competitive advantage. From the responses obtained, it was evident that the airline had excelled in reducing flight delays and improving efficiency in discharging its operations and reducing cost of operations and providing cost-efficient products and services. Moreover, the respondents asserted that continuous process improvement influenced the ability of Kenya airways to meet customers' demands through value addition, quality audit, introduction of new products and services, and the search for the best ways to improve service delivery, conducting research, tackling emerging problems and meeting the standards imposed by the regulators.

Furthermore, the respondents noted that innovation of products and services depended on invention of new service delivery methods and innovative business ideas. However, it was evident that the innovative ideas had helped to address the unmet and customer dynamic taste and preferences. The respondents observed that the customer required various types of products and services to choose from and innovation helped the organization to be ahead of its competitors by offering alternative products and services. In addition, the respondents revealed that the notable competitive advantages enjoyed by the Kenya airways as a result due to customer orientation included market differentiation, customer satisfaction and consistent loyalty. In particular brand loyalty was expressed as a major competitive issue which was brought about by customer orientation. This demonstrates that customer orientation through customer satisfaction elimination of defects and meeting the customers' needs played a critical role in enhancing competitive advantage of Kenya airways.

\subsection{Conclusions and Recommendations}

\subsection{Conclusions}

Based on the study findings, it was evident that operational efficiency, innovation of products and services, continuous process improvement and customer orientation influenced the competitive advantage of the Kenya airways. It was concluded that for the airline to achieve competitive advantage it must focus on reducing flight delays and cost of operations. The airline must also conform to its operational charter and the overall corporate strategy based on cost-efficient products and services and reliability in service delivery. With regard to innovation of products and services, the study concluded that for airlines to attain competitive advantage it must strive to offer superior products and services, explore new routes, introduce new aircrafts and offer attractive products and services. Similarly, the study concluded that for the airlines to sustain competitive advantage they should adhere to the best practices in the industry, serve customers according to the current market demand, provide a niche in quality customer service and maintain a culture of 
International Journal of Business Management, Entrepreneurship and Innovation, Volume 4, Issue 1, 2022, PP 1-19, ISSN 2707-8027

\section{BMME}

continuous improvement and learning. The study also concluded that airlines must provide products and services that are tailor made to meet the customers' needs, demands and satisfaction.

\subsection{Recommendations}

Based on the conclusions drawn from the study it is recommended that the management of Kenya airways should ensure that the operations are efficient by minimizing delays. Concerning innovation of products and services, the study recommended that Kenya airways should invest more in research to identify new products and services that will give it a competitive advantage. The study also recommends that the management of the airlines should adopt products and services that meet customers' needs and satisfaction. The management of airlines should also ensure that the services and products were accessible to the customers.

\section{References}

Adnant, M. (2017). Risk Management Practices in Islamic Airlines: An Empirical Investigation from Pakistan. Interdisciplinary Journal of Research in Business, 1, 50-57.

Akpoghiran, R. O. (2016). Customer orientation as a strategy for service awareness in Lagos Airline in Nigeria, Unpublished Master's thesis, Kwame Nkrumah University of Science and technology. .

Anderson, E. (2017). The Role of Financial Analysis Ratio in Evaluating Performance of airlines, Interdisciplinary Journal of Contemporary Research in Business, 5(2) 13-28.

Bagherzadeh, S., \& Jöehrs, P. (2015). Operational efficiency: A Practitioner's View. Journal of Risk, 5: 22-35.

Baker, A. P. (2017). The Impact of airline hubbing on the Competitive Entry in a Developing Market Upon Dynamic Pricing Strategies, Marketing Science, 5(1), 20-36.

Barney, J. (1991). Firm Resources and Sustained Competitive Advantage, Journal of Management, 17 (1): 99-120.

Barrack, J. B. (2020). Gaining and Sustaining Competitive Advantage (4 ${ }^{\text {th }}$ Edition), New Jersey: Pearson Education.

Black, D. \& William, R. (2014). Research Methods: A guide for Researchers, New York: McGraw-Hill.

Borg, W. \& Gall, J. (1989). Introduction to Educational Research. New York: Longman

Chotipanich, A. S., \& Lertariyanun, F. J. (2019). Facility management strategy in the Aviation Sector in Thailand; John Wiley \& Sons: Hoboken, NJ, USA,

Cole, N. (2015). Competing with Giants. Harvard Business Review, 77(2), 119-129.

Commer, G. S. (2019). Strategies for Surviving a Shakeout, Harvard Business Review, 75(2), 92102.

Craig, C., \& Douglas, R. (2016). Production frontiers with cross-sectional and time-series variation and efficiency levels in aviation sector, Journal of Econometrics, (4): 185-200.

Creswell, J. (2014). Research Design: Qualitative, Quantitative and Mixed Method Analysis. Nairobi: SAGE Publications.

Daud, L., \& Yusoff, G. (2017). Global airline alliances and profitability: A difference-indifference analysis, Transportation Research, 1(3): 432-443.

Erkan, M. I. (2019). Information technology at the forefront of operational strategy, The Journal of Operating risk.6, (2), 47-67.

Fredriksson, M., \& Pallas, J. (2015). Diverging principles for strategic communication in government agencies, International Journal of Strategic Communication, 10, 153-164. 
International Journal of Business Management, Entrepreneurship and Innovation, Volume 4, Issue 1, 2022, PP 1-19, ISSN 2707-8027

\section{BNED}

Gitau, G. M. (2019). Competitive advantage of selected business strategies and their impact on the overall performance of airline operators in Kenya, Unpublished Thesis, JKUAT.

Greenwood, R. (2018). The SAGE Handbook of Organizational Institutionalism. Thousand Oaks, CA: SAGE.

Gross, R., \& Luck, B. (2019). Competitive advantage in alliance constellations, Strategic Organization, 1(3): 327-335.

Hamel, T. \& Prahalad, F. (2020). International airline alliances: An analysis of code-sharing's impact on airlines and consumers, Journal of Air Transport Management, 2(2): 131-137.

Hayes, F. (2018). The empirical analysis of the impact of alliances on airline operations, Journal of Air Transport Management, 1(1): 127-134.

Hill, M., Jones, M., \& Schilling, P. C. (2018). An exploration of the relationship between managerial competencies, organizational, characteristics; and performance in Irish airlines, Journal of European Industrial Training, 3(11), 241-251.

Huang, T. (2019). A Framework for Entry Deterrence Strategy: The Competitive Environment, Choices, and Consequences, Journal of Marketing, 2(3), 44-55.

Ireland, R. D., Hitt, M. A., \& Sirmon, D. (2018). Alliance Management as a Source of Competitive Advantage, Journal of Management, 28(3): 413-446.

Jussi, J. (2016). Operational risk management in Finnish insurance companies: A Case of Company, Master's Thesis in Accounting and Finance University of Vaasa

Karanja, E. (2019). A review of competitive advantage and its role in the financial crisis of airlines in Kenya, Transactions on Basic and Applied Sciences, 16(4), 364-382.

Karimi, W. (2019). Determinants of Strategic Choices at the Kenya Airways, Journal of commerce and Business and Management, 3(5), 86-98.

Khalili, W., Nazemi, K., \& Alborzi, M. (2019). Operational Strategies and Performance of airlines: A panel model approach. Australian Journal of Business and Management Research, 3(2), 31-38.

Kibet, M. (2019). Effect of focus on marketing on Profitability of Airlines in Kenya, An Unpublished MBA Project, School of Business, University of Nairobi, Kenya.

Kipngetich, F. C. (2016). Strategic operations in ailing firms in Kenya, Unpublished master's thesis, University of Nairobi.

Kothari, C. K. (2004). Research Methodology methods and techniques, New Delhi: New Age.

Krebs, N. (2018). Collaborative strategy: an analysis of the changing organizations, Tourism Management, 2(1): 229-243.

Kulundu, C. M. (2017). Influence of operational efficiency on the competitive advantage of deposit taking savings and credit cooperatives in Bungoma County, Unpublished Thesis, University of Nairobi.

Lambkin, S. A. (2017). Factors that affect the adoption of enterprise risk management and continuous process improvement, Insight, 2(6), 253-269.

Lekhanya, C. (2018). All the Right Moves: Customer orientation and performance of airlines in South Africa, Boston, Mass: Harvard Business School Press.

Lumpkin, M. \& Dess, G. (2019). Factors Affecting Strategic Choices in Airlines: Business strategies perspective, International Journal of Business and Management, 3(5), 87-98.

Markus, P. S. (2019). Pricing strategies of low-cost airlines economic and technological advancements: The Rynair case study, Journal of air transport management, 15(195-203).

Matsilele, H. (2016). A comparative performance analysis of airline strategic alliances using data envelopment analysis, Journal of Air Transport Management, 5(2): 99-110. 
International Journal of Business Management, Entrepreneurship and Innovation, Volume 4, Issue 1, 2022, PP 1-19, ISSN 2707-8027

BMED

Mokamba, D., \& Gakure, H., Keraro, F. A. (2018). An assessment on the effectiveness of operational efficiency in selected airlines in Kenya, Unpublished Thesis, Egerton University.

Morrish, S. C., \& Hamilton, R. T. (2016). Airline alliances-who benefits? Journal of Air Transport Management, 8(3): 401-407.

Mugenda, O. M., \& Mugenda, A. G. (2012). Research methods: Quantitative and qualitative approaches. Nairobi, Kenya: Act Press.

Muiruri G. N. (2018). Strategic Responses by Firms Facing Changed Competitive Conditions, Unpublished MBA project. Nairobi: University of Nairobi

Muzellec, M., \& Lambkin, M. (2006). Credit risk and the performance of Nigerian airlines. Interdisciplinary Journal of Contemporary Research in Business, 4(7), 49-63

Naikuni, T. (2015). The nexus of service innovation and financial performance of Kenya Airways, International Journal of Economics and Entrepreneurship, 2(3), 309-311.

Ndemo, M. (2015). Cost priority in the airline operations strategy in Kenya. International Journal of Social Sciences and Entrepreneurship, 1 (2), 496-512.

Negasi, A. W. (2018). Effect of strategic continuous process improvement on customer satisfaction among mobile service providers in Kenya, Unpublished Management Research project, University Of Nairobi.

Newbert, S. L. (2018). Value, rareness, competitive advantage, and performance: a conceptual level empirical investigation of the resource-based view of the firm, Strategic Management Journal, 29(7): 745-768.

Ngari, B., \& Muiruri B. (2014). International strategic alliance performance: A multidimensional approach. International Business Review, 16 (3), 337-361.

Nur, V. Topsekele, W. \& Dogan, W. (2014). Towards a research agenda for strategic governance, risk and compliance management, Business Informatics, 15(18), 1-6

Nyamwange, D. (2001). Air Transport and Destination Performance: A case of three African countries, MPRA Paper, 14.-15.

Ofunya, Z. (2019). Competitive strategies employed by sugar manufacturing firms in Kenya, Journal of Business and Management, 3(2), 301-311

Oladepo, C. (2018). Selected Competitive approaches adopted by indigenous airlines in Nigeria, Unpublished MBA Project, University of Abuja.

Oltra, A. C. \& Flor, L. (2019). Competitive Dynamics of Inter-firm Rivalry, Academy of Management Journal, 39(2): 255-291.

Omondi, A. M. (2019). Strategies for competitive advantage employed by the airlines in Kenya, Unpublished MBA Project, University of Nairobi.

Onguko, M. A., \& Ragui, M. (2019). Strategic Positioning and its impact on Performance of the Kenya's Telecommunications Industry, Journal of Scientific Innovation and Research, 3(10), 1309-1314.

Orodho, J. (2005). Techniques of writing research proposals and reports in Education and social sciences Nairobi: Kanezja HP Enterprises.

Osborn, N. (2019). Environment and Organizational Effectiveness, International Journal of Business Management, 19(2): 231-246.

Ouma, T. H. (2018). The effect of horizontal alliances on firm productivity and profitability: evidence from the global airline industry, Journal of Transport Management, 57: 844-853. 
International Journal of Business Management, Entrepreneurship and Innovation, Volume 4, Issue 1, 2022, PP 1-19, ISSN 2707-8027

BiE.

Owino, J. P. (2019). An Assessment of the Role of operational strategies in organizational success in Kenya, International Journal of Academic Research in Business and Social Sciences 3(10).

Payne, I. \& Frow, M. (2018). Financial management, New Delhi: Vikas Publishing House.

Peteraf, M. A., \& Barney, J. B. (2003). Unraveling the resource-based tangle, Managerial and Decision Economics, 24(4): 309-323.

Porter, M. E. (2018). The Five Competitive Forces That Shape Strategy, Harvard Business Review.

Powell, T. (2001). Competitive advantage: logical and philosophical considerations, Strategic Management Journal, 2(2): 875-88.

Reid, P. (2017). Air transport: a global approach to sustainability, http://www.airportint. Com/categories/environment/air-transport-a-globalapproach-tosustainability November.

Schein, F. M. (1984). Industrial Market Structure and Economic Performance, Chicago: Rand McNally.

Sigalas, C., Economou, P., \& Georgopoulos, N. B. (2013). Developing a measure of competitive advantage, Journal of Strategy and Management, no. 6(4).

Skinner, R. H. (1969). Factors Influencing Partner Selection in Strategic Alliances: The Moderating Role of Alliance, Strategic Management Journal, 471-494.

Slack, D. (2010). The Market Makers. New York: McGraw-Hill.

Statista. (2017). Leading airline alliances in 2017 by market share, revenue. Retrieved from https://www.statista.com (11 December 2018).

Sundaram, G. \& Al-Aali, J. (2019). A Framework for Entry Deterrence Strategy: The Competitive Environment, Choices and Consequences, Journal of Marketing, 59(3), 44-55.

Sundus, E., \& Naintara, M. (2018). The impact of performance measurement in strategic planning. International journal of productivity and management, 54 (5): 370-384.

Tamale, A. (2017). Governance, Risk, and Compliance Handbook: Technology, Finance, Environmental and International Guidance and Best Practices; John Wiley \& Sons: Hoboken, NJ, USA.

Tanui, B. (2015). Governance structure choice in strategic alliances: The roles of alliance objectives, alliance management experience, and international partners, Management Decision, 1(5): 725-742.

Theuri, A. (2010). Analysis of Global Airline Alliances as a Strategy for international network development. Transportation Research, 28(5), 415-431.

Türkay, O. (2016). Strategic analysis of the external environment and the importance of the information: Research on perceptions of hotel managers. Procedia-Social and Behavioral Sciences, 24, 1060-1069.

Urbancová, C. (2013). Assessing the price effects of airline alliances on complementary routes in the Czech Republic, Transportation Research, 47(3), 315-332.

Wandiga, T. \& Kilika, H. (2017). Sustainable competitive advantage or temporary competitive advantage: Improving understanding of an important strategy construct, Journal of Strategy and Management, 1(2): 168-103.

Wang, S. W. (2018). Do global airline alliances influence the passenger's purchase decision? Journal of Management, no. 37: 53-59.

Wanyiri, T. (2010). Kenya Airways on half-year net loss as it counts on even lower profit, Monthly Publication by Bizrika.

Waters, B. (2006). Decision making in the aviation sector: Cost Benefit Analysis Project completion and Innovation, International Journal of Management, 29(5) 740-60 
International Journal of Business Management, Entrepreneurship and Innovation, Volume 4, Issue 1, 2022, PP 1-19, ISSN 2707-8027

Werner, A. (2019). Determinants of customer expectations in the service industry, Academy of Marketing Science, 21(1), 1-12.

Whipple, J. M., \& Frankel, R. (2000). Strategic Alliance Success Factors, The Journal of Supply Chain Management, 6(2): 21-28.

White, D. (2015). Defensive and Offensive Strategies for Market Success, International Journal of Business and Social Science, 2(3), 1-12.

Winston, F. \& Crandall, P. (2014). Competitive strategies for performance of firms in the carpeting sector, Social Science Journal, 14, 309-324.

Zafar, W. (2019). Consequences of strategic alliances between international airlines: the case of Swissair and SAS. Transportation Research, 28(3), 415-431.

This is an open-access article published and distributed under the terms and conditions of the (c) (7) \&) Creative Commons Attribution 4.0 International License of United States unless otherwise stated. Access, citation and distribution of this article is allowed with full recognition of the authors and the source. Copyright, content ownership and liability for content herein remain with the authors. 